\title{
AN OPTIMAL LEVEL OF TECHNOLOGY RELIANCE ON FOREIGN PARTNERS IN A GLOBAL SOURCING PARTNERSHIP: COMPONENTS PROCUREMENT, TECHNOLOGY MANAGEMENT AND MARKET PERFORMANCE
}

\author{
Masaaki Kotabe \\ Associate Professor of Marketing and International \\ Business; Ambassador Edward Clark Centennial Fellow, \\ Director of Research at the Center for International \\ Business Education and Research, The University of \\ Texas at Austin. \\ E-mail: Kotabe@mail.utexas.edu \\ Preet S. Aulakh \\ Assistant Professor of Marketing and International \\ Business at Michigan State University.
}

SUMÃRIO: Os estudos sobre estratégia de suprimento global têm adotado uma perspectiva de sistemas fechados, nos quais as atividades de suprimento sāo gerenciadas dentro de uma empresa multinacional através de fronteiras nacionais. Inovaçāo em processos de manufatura e suprimento de componentes gerenciados conjuntamente por um consórcio de empresas ainda nāo foram devidamente examinados. Neste artigo, abordaremos as questōes concernentes a parcerias de suprimento em sistemas abertos. Os resultados de nosso estudo sugerem que mesmo em uma parceria de suprimento com um fornecedor estrangeiro, a principal habilidade da empresa para obter e controlar o fornecimento dos componentes principais tem uma correlaçāo positiva com seu desempenho de mercado.

ABSTRACT: Existing studies on global sourcing strategy have implicitly adopted a closed-systems perspective in which sourcing activities are managed within a multinational company across national boundaries. Product and process innovations and components procurement that are jointly managed by a consortium of cooperating firms have not been examined. In this paper, we empirically examine the issues concerning sourcing partnerships in an open-systems perspective. Findings suggest that even in a sourcing partnership arrangement with a foreign supplier, the principal firm's ability to procure and control the supply of major components has a positive bearing on its market performance.

PALAVRAS-CHAVE: atividades de suprimento, gerência de tecnologia, suprimento de componentes, desempenho de mercado.

KEY WORDS: sourcing activities, technology management, components procurement, marketing performance. 
Global sourcing strategy has been the subject of attention of many researches in the past twenty years. Particularly in the last decade this research stream has picked have been recognized in creating and integrating various business operations across national boundaries. ${ }^{2}$ This has resulted in an increasing number of multinational firms engaged in sourcing of components and products on a global scale.

While the purchasing literature on global sourcing ${ }^{3}$ has provided tactical and up dramatically ${ }^{1}$, as numerous advantages

operational details (i.e., dos and don'ts, cost issues), it generally has not addressed the strategic issues of global sourcing such as product policy, technology management, and market performance. In recent years, however, research on global sourcing strategy has not simply centered around where and how ${ }^{6}$ to procure crucial components and products, but also around how to manage product and process technology internationally in relation to product development.

Global sourcing strategy is conceived broadly as global management of R\&D, manufacturing, and marketing interfaces. So far, most sourcing studies have focused on internal/external procurement of core components as a means to enhance a firm's competitive advantage in the global market. The significant extent of internal sourcing used by multinational firms is well documented in the global sourcing literature, but it was not until recently that performance implications were explicitly examined. These studies generally suggest that the firm's in-house capability to procure core components has a direct bearing on its market performance. This finding is consistent with the predictions of the internalization theory ${ }^{10}$ and also with the core competency argument popularized by Prahalad and Hamel. ${ }^{11}$

However, these sourcing studies have implicitly assumed a closed-systems perspective in which sourcing activities (i.e., including product and process innovations and components procurement) are managed within a multinational company across national boundaries. In the last decade or so, we have seen a tremendous growth of sourcing partnership arrangements as a mean to accomplish competitive advantage in the face of turbulent global competition characterized by high product development cost and time-tomarket pressure. ${ }^{12}$ In particular, Japanese keiretsu sourcing partnerships in the automobile industry have been highlighted as a special case. ${ }^{13}$ In a partnership, two or

1. CARTER, Joseph R., NARASIMHAN, Ram. Purchasing in the international marketplace. Journal of Purchasing and Materials Management v. 26, p. 2-11, Summer 1990; KOTABE, Masaaki Global sourcing strategy: R\&D, manufacturing and marketing interfaces Westport CT: an Ouorum Books, 1992.

2. JOHANSSON, Johnny K., YIP, George S Exploiting globalization potential: U.S. and Japanese strategies. Strategic Management Joumal. v. 15, p. 579-601, October 1994; PORTER, Michael E. (ed.) Competition in
global industries. Boston, MA: Harvard global industries. Boston, MA:
Business School Press, 1986.

3. BIROU, Laura M., FAWCETT, Stanley E. International purchasing: benefits, requirements, and challenges. Intemationa Journal of Purchasing and Materials Management, V. 29, p. 28-37, Spring 1993;

4. KOTABE, M. Op. cit; NISHIGUCHI, Toshihiro. Strategic industrial sourcing: The Japanese advantage. New York: Oxford University Press, 1994.

5. GRUNWALD, Joseph, FLAMM, Kenneth. The global factory: Foreign assembly in intemational trade. Washington, D.C.: The Brookings Institution, 1985; SWAMIDASS Paul, KOTABE, Masaaki. Componen sourcing strategies of multinationals: an empinical study of European and Japanese multinationals. Journal of Internationa Business Studies. v. 24, p. 81-99, First Quarter 1993.

6. KOTABE, Masaaki, OMURA, Gienn S. Sourcing strategies of European and Japanese Multinationals: a comparison. Joumal of International Business Studies. 20, p. 113-130, Spring 1989; KOTABE. Masaaki and SWAN, K. Scott. Offshore sourcing: Reaction, maturation, and consolidation of U.S. multinationals. Journ of International Business Studies v 25 . 115-40, First Quarter 1994; NISHIGUCHI, T., Op. cit.

7. KOTABE, M. Op. cit., 1992.

more firms contribute their respective superior technology and/or know-how to make it possible what could not otherwise be achieved by each individual firm.

Product and process innovations and components procurement that are jointly managed by a consortium of cooperating firms in a sourcing partnership have not been examined in the U.S. environment. Thus, the ability of the earlier normative findings to be generalized to this new form of organization (i.e., an open-system) remains moot. In this study, besides extending it, we address the limitations of existing global sourcing research by examining the impact of product and process innovative activities and components procurement on the market performance of firms that have a sourcing partnership arrangement.

\section{Global Sourcing Strategy and Sourcing partnerships}

In this section, we discuss fundamental issues of sourcing partnership arrangement concerning the principal firm's exercise of
8. United Nations Center on Transnational Corporations. Transnational corporations in world development: Trends and perspectives. New York: United Nations, 1988.

9. OHMAE, Kenichi. The global logic of strategic alliances. Harvard Business Review. v. 67, p. 143-155, March-April 1989; MURRAY, Janet Y., KOTABE, Masaaki, WLDT, Albert R. Strategic and financiai performance implications of global sourcing strategy: A contingency analysis. Joumal of internationa Business Studies. v. 26, p. 181-202, First Quarter 1995.

10. BUCKLEY, Peter J., CASSON, Mark. A theory of cooperation in international business. In: Cooperative strategies in
intermational business, Farok J. Contractor and Peter Lorange eds. Lexington,
Lexington Books, 1988, p. 31-53.

11. PRAHALAD, C.K., HAMEL, Gary. The core competency of the corporation. Harvard core competency of the corporation. Harvard
Business Review. v. 68, p. 79-91, May-June Business
1990.

12. HAMEL, Gary, Doz, Yves L., PRAHALAD, C. K. Collaborate with your competitorsand win. Harvard Business Review. v. 67, p. 133-139, January-February 1989; OHMAE Kenichi. Triad Power. New York: The Free Press, 1985.

13. ASANUMA, Bann. The organization of parts purchases in the Japanese automobile industry. Japanese Economic Studies, v. 15 , p. 32-53, Summer 1985; CUSUMANO, Michael A., Takeishi, Akira. Supplier relations and management: A survey of Japanese, Japanese-transplant, and U.S. auto plants. Strategic Management Journal, v. 12, p. 563588, November 1991; RICHARDSON, industry. Strategic Management Joumal, v. 14, p. 339-350, July 1993. James. Paraliel sourcing and supplier 
14. KOTABE, M., Op. cit., 1992.

15. ANDERSON, ERII, GATIGNON, Hubert. Modes of foreign entry: $A$ transaction cost analysis and propositions. Journal of international Business Studies. v. 17. p. 1-26. Fall 1986; BUCKLEY, Peter J., CASSON, Mark. The Future of the Multinational Enterprise. London: Macmillan 1976; GROSSMAN, S. and HART, 0 . D. The costs and benefits of ownership: A theory of vertical and lateral integration. Journal of Political Economy, v. 94, n. 4, p. 691-719, 1986; KLEIN, Saul FRAZIER Gary L., ROTH, Victor J. A transaction cost analysis model of channel integration in international markets. Journal of Marketing Research. v. 27, p. 196-208, May 1990

16. KOTABE, M. Op. cit., 1992; KOTABE, M., SWAN, K. S. Op. cit. 1994

17. KUMPE, Ted, BOLWIJN, Piet T. Manufacturing: The new case for vertical integration. Harvaro Business Review. v. 66, p. 75-81, March-April 1988.

\section{FIGURE 1}

\section{Sourcing strategy factors}

- Extent of internal sourcing

- Product innovation

- Process innovatiom

Market performance

- Market share

- Sales crowth rate

Sourcing partnership factors

- Extent of reliance on

partner for technology

(Product and process)

- extent of operational control

control and technical reliance on its foreign partners, as well as traditional sourcingrelated issues including product and process innovative activities and procurement of core components. For sourcing issues, we build on Kotabe's prior work. ${ }^{14}$ For partnership issues, we draw primarily from existing research on control in foreign markets. ${ }^{15}$ The study promises to offer multinational executives in charge of corporate planning and sourcing partnerships some crucial insight into the mechanism of developing and implementing a successful global sourcing strategy with foreign partners. A conceptual framework presented in figure 1 represents traditional sourcing and sourcing partnership factors as determinants of the principal firm's market performance.

\section{Internal Sourcing vs. Production Sharing}

Effective global sourcing has been recognized to enhance a firm's competitiveness, so the multinational firms' concern is not whether to engage in global sourcing, but how to select an appropriate global sourcing strategy to achieve their business objectives. In general, multinational firms can source components and products in two ways: (1) procuring them within the corporate system (a closed-system of internal sourcing)-either a parent from its subsidiaries, or subsidiaries from their parent or from other subsidiaries, and (2) procure from independent suppliers outside the corporate system, on a contractual basis (an open-system of external sourcing). Recent empirical studies ${ }^{16}$ have shown that global sourcing of major components influences a firm's market performance, provided that these activities are carried out on an intra-firm basis (internal sourcing).

According to those studies, the competitive benefit of internal sourcing (whether domestically or from abroad) seems to be attributed to the multinational firms' capability to contain three negative consequences of relying on independent contractual suppliers in the long run. First, to ensure the quality of the components, the firm tends to forsake part of the most important value-creating activities to independent operators and also become dependent on them. ${ }^{17}$ Second, those multinational companies tend to promote competition among independent suppliers, ensure continuing availability of materials 
in the future, and exploit full benefits of changing market conditions. However, individual suppliers are forced to operate in an uncertain business environment which inherently necessitates a shorter planning horizon. The uncertainty about a potential loss of orders to competitors, often forces individual suppliers to make operating decisions that will likely increase their own long-term production and material costs. ${ }^{18}$ This process tends to adversely affect U.S. companies sourcing components and/or finished products that come from those contractual suppliers.

Third, the management of the quality of major components is required to retain consumers' goodwill and confidence in the quality and reliability of finished products. ${ }^{19}$ As a result, internal sourcing of major components and finished products between the parent company and its affiliates abroad, and between its foreign affiliates themselves, would enable the company to retain a long-term competitive edge built on quality, reliability, and customers confidence, among other things. Thus, continual sourcing from independent suppliers even tends to forebode those companies long-term loss of the ability to manufacture at competitive cost and, as a result, loss of their long-term global competitiveness.

However, if technology and expertise developed by a multinational company are exploited within its multinational corporate system (i.e. by its foreign affiliates and by the parent company itself), the company can retain its technological base to itself without unduly disseminating them to competitors as though it were a "public" good. According to internalization theory, the benefit of such internalization is great, particularly when technology is highly idiosyncratic or specific, with limited alternative use, or when it is novel in the marketplace. It is so because its true economic value to the firm tends to be undervalued in the marketplace due to the uncertainty associated with the technology as it is perceived by potential buyers.

While the above closed-systems argument for increased internal sourcing of core components has received a good

Most sourcing studies have focused on internal/external procurement of core components as a means to enhance a firm's competitive advantage in the global market.

deal of anecdotal, empirical, and theoretical support, a counterargument, based on the increased $R \& D$ costs and the importance of speed-to-market in an era of global competition, has also gained support. ${ }^{2}$ This school of thought, popularized in the 1980s, argues that many successful companies have developed a dynamic organizational network through increased use of joint ventures, subcontracting and licensing activities across international borders. This flexible network system is broadly referred to, here, as sourcing partnerships, or it has also been known as production sharing.

As further reinforced by Prahalad and Hamel, ${ }^{24}$ companies have been strongly encouraged to develop world-class core competence in some areas of the value chain in the industry. In recent years, dynamic models of competition, such as theory of competitive rationality ${ }^{25}$ and theory of hypercompetition, ${ }^{26}$ have also begun to emerge, emphasizing competitive urgency as a result of rapid technological change and competitive pressure. These conceptualizations suggest an inherent difficulty in gaining a superb competitive advantage in every aspect of business in an industry. Thus, production sharing allows each participant to pursue its particular core competence, thereby maintaining a nimble competitive position in a very fluid competitive environment. Therefore, each network participant can be seen as complementing rather than competing with the other participants for the common goals. Production sharing may even be formed by competing companies in the same industry, in pursuit of complementary abilities (new technologies or skills) from each other.
18. HAHN, Chan K., KIM Kyoo H., KIM, Jong S. Costs of competition: Implications for purchasing strategy. Journal of Purchasing and Materials Management. v. 22, p. 2-7, Fall 1986.

19. KOTABE, M. Op. cit., 1992.

20. MARKIDES, Constantinos, BERG, Norman. Manufacturing offshore is bad business. Harvard Business Review, v. 66, p. 113120, September-October 1988; MORGAN, James C., MORGAN, J. Jeffrey. Cracking the Japanese Market: Strategies for Success in the New Global Economy. New York: The Free Press, 1991.

21. BUCKLEY, P., CASSON, M., Op. cit., 1976; DUNNING, John H. The eclectic paradigm of international production: A restatement and some possible extensions. Journal of International Business Studies. v. 19, p. 1-31, Spring 1988.

22. MILES, Raymond E., SNOW, Charles C. Organizations: New concepts for new forms. California Management Review. v. 28 , p. $62-73$, Spring 1986; Organization for Economic Cooperation and Development. Intra-Firm Trade. Paris: OECD 1993; Ohmae, Kenichi, Op. cit.

23. DRUCKER, Peter F. Production sharing, concepts and definitions. Journal of the Flagstaff Institute. v. 3, p. 2-9, January 1979; KIM, W. C. Global production sharing: An empirical investigation of the Pacific electronics industry. Management International Review. v. 26, p. $62-70,1986$; NISHIGUCHI, T., Op. cit.

24. PRAHALAD, C.K., HAMEL. G., Op. cit.

25. DICKSON, Peter R. Toward a general theory of competitive advantage. Journal of Marketing. v. 56, p. 69-83, January 1992.

26. D'AVENI, Richard. Hypercompetition: Managing the dynamics of strategic maneuvering. New York: The Free Press, 1994. 
27. CAPON Noel, GLAZER, Rashi. Marketing and technology: A strategic coalignment. Journa/ of Marketing. v. 51, p. 1-14, July 1987

28. MANSFIELD, Edwin. Industria R\&D in Japan and the United States: A comparative study. American Economic Review, v. 78, p. 223 228, May 1988: UTTERBACK James $M$. Innovation and industrial evolution in manufacturing industries. In: Technology and global industry. Bruce R. Guile and Harvey Brooks eds. Washington, D.C. National Academy Press, 1987, p. 16-48.

29. KOTABE, M. 1992, Op. clt. MURRAY, J., KOTABE, M., WILDT. A R. Op. cit.

30. ABERNATHY William. J., UTTERBACK, John M. Patterns of industrial innovation. Technology Review, v. 80 , p. $40-47$, June-July 1978; VERNON, Raymond. The product cycle hypothesis in a new international environment. Oxford Bulletin of Economics and Statistics. v. 41, p. 255-267, November 1979

31. HAGEDOORN, John Understanding the rationale of strategic technology partnering: Interorganizational modes of cooperation and sectora differences. Strategic Management Joumal, v. 14, p. 371-385, 1993.

32. D'AVENI, R., Op. cit.;

33. TEECE, David J. Capturing value from technological innovation integration, strategic partnering, and licensing decisions. In: Technolog and Global Industry Bruce R. Gulle and Harvey Brooks. eds. Washington, D.C.: Nationa Academy Press, 1987, p. 65-95

34. BUCKLEY, P. CASSON, M. 1988, Op. cit.; DICKSON, P., Op. cit.

35. HAMEL, G., DOZ, Y. L. PRAHALAD, C. K., Op. cit.; KOGUT Bruce, Joint ventures: Theoretica and empirical perspectives. Strategic Management Joumal. v. 9 p. 319-332, 1988 .

36. HAGEDOORN, J., Op. cit.
While there are no empirically tested results to show the impact of production sharing on the firms' market performance, this open-systems school of thought is conceptually appealing and casts some doubt on the continual validity of the closed-systems school of thought.

Therefore, we hypothesize that internal sourcing of core components has a positive impact on the firms' market performance up to a point beyond which the flexibility of production sharing with contractual suppliers begins to outweigh the value of internal sourcing. In other words,

H1: An inverted U-shape relationship exists between the extent of internal sourcing and the principal firm's market performance.

- Product and Process Innovations. Innovation is generally defined as knowhow composed of product technology (the set of ideas embodied in the product) and process technology (the set of ideas involved in the manufacture of the product or the steps necessary to combine new materials to produce a finished product). Foreign multinational firms-German and Japanese competitors, in particular-have enjoyed an enormous success in the U.S. market with their strong commitment to gaining competitive advantage through internal development of advanced process technology, complementing the value of product technology. ${ }^{28}$ This interactive nature of product and process technology has been empirically shown to give major foreign competitors a competitive advantage over U.S. firms. This is because, alone, the technological superiority of a firm's product tends to be of short-lived economic significance unless it is backed by complementary process capacities which allow the firm to capture returns from product innovation for a longer period of time.

- Accelerated Product Development. Historically, the international product cycle model has been instrumental in explaining this diffusion of product innovations in international commerce and the increased importance of process innovations over time and space. In the last decade or so, however, increased global competition has resulted in shorter product life cycle, rapid price reduction, and eroding profit margins. Since new product innovations determine many firms' competitive strength, pressure to innovate and market new products around the world has grown tremendously in recent years. Firms must improve their speed and chance of introducing successful innovations. ${ }^{31}$ This accelerated technological environment further demands a more significant product innovation and a faster implementation for a firm to stay ahead of competition than in the past. As a result, increasingly innovative products are introduced in a shorter time interval around the world. ${ }^{32}$ Therefore, it is expected that product innovations have become a more important determinant of a firm's market performance than process innovations.

H2: Product innovations have a more favorable impact on the firm's market performance than process innovations.

- Technology Reliance. In many industries experiencing rapid technological change, however, a single company rarely has the full range of expertise needed to offer timely and cost-effective new product innovations around the world. ${ }^{33}$ In fact, a turbulent, uncertain environment serves to increase the motivation to cooperate and innovate. ${ }^{34}$ In order to reduce enormous development costs, lessen inherent risks of product introduction, and access technology/know-how unavailable internally, many firms have shifted their modus operandi from internal development to cooperative ventures. ${ }^{35}$ This opensystems view complements the clear resource and institutional constraints on a firm's behavior and the motives of interfirm technology cooperation, inherent in dynamic models of competition. ${ }^{36}$

However, several researchers have argued that a principal firm's reliance on its partner(s) for product and process innovative activities have a different impact on the company's market performance for two major reasons. First, given the increased technological parity 
among many competitors today, new product innovations are relatively easily reverse-engineered, improved upon, and reinvented by competitors without unduly violating patents and other proprietorial protections bestowed on them. Therefore, a principal firm cooperating with a partner company for product innovations will not likely maintain a monopolistic grip on product technology which has become an increasingly important source of competitive strength.

H3: The more dependent a principal firm is on its partner company for product innovations, the lower the principal firm's market performance.

Second, when a partner company has strong manufacturing process capabilities, their competitive benefit to a principal firm is obvious. However, a principal firm's increasing reliance on its partner's process capabilities tends to be detrimental to the principal firm as process technology is inherently much more difficult to learn than product technology. In the long run, the principal firm tends to lose sight of emerging technologies and expertise that could be incorporated into the development of new manufacturing processes as well as new products. After all, the creation of new technology is a gradual and painstaking learning process of continual adjustment and refinement, as new productive methods are tested and adapted in the light of a company's accumulated experience. Further, stressing the historical linkage of product and product innovations, Brooks ${ }^{39}$ contends that manufacturing process learning (followed by more innovative adaptation, leading to pioneering product innovation) forms the natural sequence of industrial development. Thus, over-reliance on process technology from others may not result in the same sustainable competitive advantages available through internal development. ${ }^{40}$ Therefore,

H4: An inverted U-shaped relationship exists between the extent of the principal firm's reliance on its partner company's

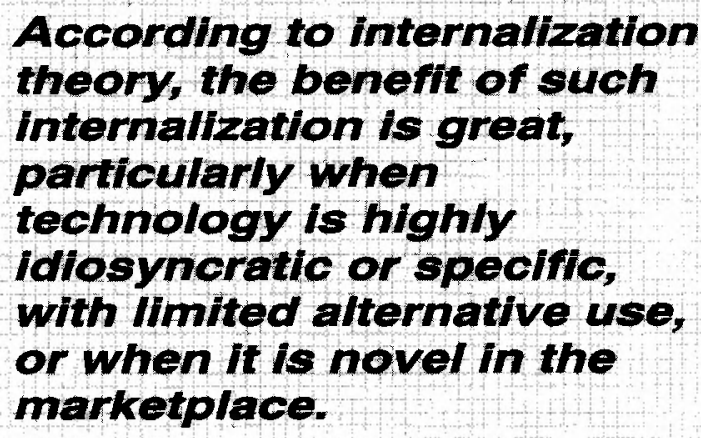

manufacturing process technology and the principal firm's market performance.

\section{Vertical Control}

As discussed in the previous sections, empirical studies on global sourcing have found a positive relationship between internal sourcing of core components and market performance. This finding is consistent with transaction cost analysis (TCA)/internalization theories which suggest that dependence on outside firms for important product and process technologies creates a hostage situation for the principal firm because of the threat of opportunistic behavior from the part of the foreign partners. Thus the principal firm is better off internalizing the transactions (i.e., internal sourcing) in order to mitigate the risk of opportunistic behavior by the foreign partners (because internalization through hierarchical ownership structures allows the principal firm to control all its activities along the value chain).

While control over all activities through internal sourcing has been shown to have important implications for market performance, the TCA/internalization theories do not address control issues in inter-firm sourcing partnerships (considered in this study). Recent research in a variety of disciplines suggests that control is not synonymous with ownership but is the ability to exercise influence over decision-making. ${ }^{41}$ Accordingly, when complete integration is not feasible, a quasiintegration can be achieved in relationships between independent firms by establishing vertical control. ${ }^{42}$ This implies that, in interfirm sourcing partnerships, the principal
37. LEVIN, R. C., KLEVORICK, A. K., NELSON, R. R., WINTER S. G.' Appropriating the returns from industrial research and development. Brookings Papers on Economic Activity. Issue 3. 1987. p. 783-831; KOTABE, M. 1992, Op. cit.

38. BR0OKS, Harvey. Japanese technological advances and possible United States responses using research joint ventures Presented at House Subcommittee on Investigations and Oversight and the Subcommittee on Science, Research, and Technology of the Committee on Science and Technology, 98th Congress, 1st session. June 29-30, 1983; REICH, Robert B., MANKIN, Eric D., Joint ventures with Japan gives away our future. Harvard Business Review, v. 64 , p. 78-86. March-April 1986; STINCHCOMBE, Arthur L. Norms of exchange. In: Stratification and Organization: Selected Papers, A.L. STINCHCOMBE. ed., Cambridge, UK: Cambridge University Press. 1985. p. 231-267.

39. BROOKS, H., Op. cit.

40. CANTWELL, John Technological Innovation and Multinational Corporations. Oxford, UK: Basil Blackwell Ltd. 1989; HAYES, Robert H., WHEELWRIGHT, Stephen C. CLARK, Kim B. Dynamic manufacturing: Creating the learning organization. New York: The Free Press, 1988.

41. AULAKH, Preet S. Contro mechanisms in cross-nationa marketing relationships: An empirical investigation into international licensing and export operations, a Ph.D. dissertation The University of Texas at Austin. 1995; GROSSMAN, S. and HART, 0 . D. The costs and benefits of ownership: A theory of vertical and lateral integration. Journal of Political Economy. v. 94, n. 4, p. $691-719,1986$.

42. HEIDE, Jan B., JOHN, George Do norms matter in marketing relationships, Journal of Marketing. v. 56, p. 32-44, April 1992; STINCHCOMBE, A. L., Op. cit. 
firm can exercise vertical control over the activities performed by the partner firm. For instance, since an important issue in inter-firm sourcing partnerships is the component's quality and reliability, the principal firm can monitor the manufacturing activities of the foreign partner, thus ensuring quality standards. This allows the principal firm vertical control over foreign partner's activities which is the functional substitute for ownership in nonintegrated situations. Thus, the principal firm achieves the same control benefits of internal sourcing in external sourcing relationships by establishing vertical control over partner activities. ${ }^{43}$ Vertical control will, in turn, be positively related to market performance since such control ensures a continuous and timely supply of sourcing components which meet the quality expectations of the principal firm and its customers. Based on these arguments, it is expected that:

\section{Control is not}

\section{synonymous with} ownership but is the ability to exercise influence over decision-making.

H5: A positive relationship exists between the extent of vertical control exercised by the principal firm on the foreign partner's activities and the principal firm's market performance.

\section{METHOD}

\section{Research Setting and Data Collection}

The hypothesized relationships were empirically tested through a survey using cross-sectional data. The first step in the data collection process was to identify the target sample of firms. The initial sample frame identified was the Fortune's 500 U.S.
This target sample was considered appropriate because, first, these firms are likely to have sourcing partnerships with firms in foreign countries. Second, industrial firms usually are involved with the transfer of product and process technologies, thus making them suitable for testing the proposed hypotheses.

The data collection was accomplished in two stages. In the first stage, the presidents/CEOs of the Fortune's 500 Industrial Firms and their major affiliates were contacted by mail. A personalized letter along with a summary of the proposed research and a contact form was mailed requesting their cooperation with the study and asking them to provide the names of two executives who managed the respective firms international sourcing partnerships. For operational purposes, sourcing partnerships were defined as coproduction with a foreign partner involving a licensing agreement. This form of partnership is the most representative of sourcing partnership's alliances for industrial firms.

In the second stage of the data collection, the 301 managers identified in stage one were contacted by mail. A cover letter summarizing the purpose of the research and a pre-tested and purified questionnaire were mailed, along with a postage pre-paid return envelope. Two follow-up letters were sent to these managers at an interval of a month each. The managers were asked to choose one sourcing partner in a foreign country that they were most familiar with and to answer all questions with respect to the firms relationship with the chosen partner. Managers were also asked to provide additional information about firm characteristics and informant characteristics. After three mail-outs, 110 completed questionnaires were received for an effective response rate of $36.5 \%$.

The problems associated with reliance on a single informant per unit of analysis have been noted in literature as it may not allow either an assessment of the reliability of the informant's reports or an assessment of potential sources of errors in such reports. Given the concerns about single informants, extreme care was taken to ensure that appropriate respondents filled 
the questionnaire. First, the CEOs / presidents of the companies were contacted and they were asked to identify the managers who actually deal with foreign partnerships. Second, the job titles of the actual respondents showed that they all hold mid- to upper-management positions, and would therefore be involved in decision-making regarding the firm's foreign operations. Finally, the informants' characteristics suggest that they have an extensive experience in the firm and in dealing with the foreign country from which they had selected the partner. The informants had on average 11.7 years of experience within their respective firms and 8.2 years of experience in dealing with the firm's operations in the country they had selected. Overall, the quantity of the responses and the quality of the respondents, along with a high level of interest and enthusiasm for the study, expressed by the participants, were considered adequate for the testing of the hypotheses.

\section{MEASURES}

The measures used for this study are presented in the Appendix. Several of the variables were assessed by using multipleitem measures, for which Cronbach's alphas are reported.

Extent of Internal Sourcing: Earlier studies have consistently found that the firm's ability to procure major components internally is positively related to its market performance. In this present study, some doubt has been cast on the validity of a linear relationship between extent of internal sourcing and market performance, particularly in a sourcing partnership.

Consistent with the earlier studies, the extent of internal sourcing was operationalized in two alternative ways: 1) as the percent of the total value of components in the product, sourced from the principal firm (SOURCE1), and 2) as the percent of the total value of major components in the product, sourced from the principal firm (SOURCE2). For the second operational measure, major components were defined as those components that could not be sourced from local firms in newly industrialized countries (e.g., Taiwan, South Korea, and Singapore) without technical assistance (i.e., with blue-print specifications only) from the principal firm. Therefore,

\section{SOURCE2 = SOURCE1 $\times(1$-STDCOMPO $)$,}

where STDCOMPO = those components that could be sourced from local firms in newly industrialized countries without technical assistance from the principal firm.

Product and Process Innovations: As Utterback $^{44}$ stated, it is inherently difficult to measure the level of product and process innovations quantitatively, since they are inextricably interdependent. For example, in considering manufacturing innovation, both a product line and an associated process must be taken together as the unit of analysis. Thus, a product innovation typically contains a patent that protects its manufacturing process. ${ }^{45}$ Objective measures of R\&D intensity as a proxy for innovativeness generally lump product and process innovations together. Besides, many studies, such as a seminal work by Hufbauer ${ }^{46}$ have used aggregate industry data, which may not disclose strategic variations among different products. It is also possible that aggregate industry data may not reflect a management's view of a product. Therefore, consistent with earlier studies on global sourcing strategy, management's perception of the levels of product innovation (i.e., the set of innovative ideas involved in the product itself) and process innovation (i.e., the set of innovative ideas involved in the manufacturing process), relative to competitors in the foreign market, were measured on a 5-point scale.

\section{Technology Reliance on Partner Firm:} In a sourcing partnership, two or more firms contribute their respective superior technology and/or know-how to make it possible what could not otherwise be achieved by each individual firm. In this study, the level of technology reliance was measured from a principal firm's perspective. Respondents were asked to
44. UTTERBACK, J., Op. cit.

45. STOBAUGH, Robert. Innovation and Competition. Boston, MA: Harvard Business School Press, 1988.

46. Idem, ibidem. 


\section{In a sourcing partnership, two or more firms contribute their respective superior technology and/or know-how to make it possible what could not otherwise be achieved by each individual firm.}

rate, on a percentage basis, the level of their foreign partners contribution to the product and process innovations represented in the product $(0 \%=$ no reliance to $100 \%=$ complete reliance).

Vertical Control: While ownershipbased control may not be exercised by the principal firm in a sourcing partnership, it will nonetheless exercise vertical control over the activities performed by its foreign partners to ensure sourcing effectiveness, mainly, the quality and reliability of product and/or components. The principal firm's vertical control over the foreign partner was represented by means of five items measured on a 5-point scale (Cronbach $\mathrm{a}=.78$ ). Those five items relate to the principal firm's monitoring of the quality control maintained by the foreign partner, the marketing activities of the partner, the extent to which the partner follows established procedures, the developing of specific procedures for the partner to follow, and the making sure that the partner handled its business conforming to the principal firm's operational specifications.

Market Performance: Market performance is a multi-faceted construct. ${ }^{48}$ To make it possible the comparison of our study findings with those of earlier studies on global sourcing strategy, the products' market performance was defined, here, to include market share, sales growth rate, and product quality (measured in relation to the competitors in the principal foreign market). The three items were measured on a 5-point scale and the items' mean was used to represent market performance (Cronbach $\mathrm{a}=.85$ ).
Control Variables: although no specific hypotheses were developed, we suspected that product type, firm size, and target market location might have some bearing on the principal firm's market performance. Therefore, the following three variables were included in the market performance analysis as control variables.

Firm Size: This variable is measured by three open-ended questions about the principal firm's worldwide dollar sales, U.S. employment, and worldwide employment. Since the measurement units of the three items are not identical, the items were standardized and their mean was used to represent firm size (Cronbach $a=.94)$.

Product Type: Product type is a dichotomous variable representing either industrial (0) or consumer (1) products.

Target Market Location: This variable identifies the foreign product market served by the principal firm-foreign partner alliance. For operational purposes, the market location was classified into either developed country market (1) or developing country market $(0)$.

\section{ANALYSIS AND RESULTS}

The existence of optimum conditions was hypothesized for the extent of internal sourcing (H1) and the extent of the principal firm's reliance on its partner company's manufacturing process technology (H4) to maximize the principal firm's market performance. While the extent of the principal firm's reliance on its partner company's product technology was hypothesized to be linearly (and negatively) related to its market performance $(\mathrm{H} 3)$, there was a modicum of concern that an optimum level of product technology reliance might also exist for the best market performance. Therefore, the square terms of the three predictor variables were included in the regression analysis. However, the square terms of the predictor variables tend to be correlated with their original terms; all predictor variables, except for product type and target market location (dummy variables), were standardized to reduce
48. BUZZELL, Robert D., GALE, Bradley T. The PIMS Principles. New York: The Free Press. 1987. 
multicollinearity problems in the regression model.

Market performance was regressed on the predictor and control variables. Two alternative measures for the extent of internal sourcing, SOURCE1 and SOURCE2, were employed in separate regression analyses. The results of the two regression analyses were found to be virtually identical. Furthermore, in either analysis, two of the control variables, firm size and product type, were insignificant $(p>20)$ and were deemed to have no significant bearing on market performance. These two control variables were deleted from subsequent analysis. As the regression model with SOURCE1 had an explanatory power (R2) of $36.1 \%$ as opposed to the one with SOURCE2, having $\mathrm{R} 2$ of $39.0 \%$, the results of the latter regression analysis are presented in Table 1.

H1: The crux of this hypothesis is that there is an optimum level of internal sourcing of major components for best market performance, beyond which some diseconomies begin to outweigh the benefit of internal sourcing. In other words, it was expected that the square term of the extent of internal sourcing would have a negative coefficient while its linear term would have a positive one. Results show that the linear term was significant $(\mathrm{p}=.04)$ while the square term was not $(p=.25)$, although the signs were both in the expected direction. Therefore, this finding is consistent with Kotabe's and his associates' earlier studies that the higher the extent of internal sourcing of major components, the better the company's market performance. Thus, for major components, the production sharing argument of Miles and Snow ${ }^{50}$ and Prahalad and Hamel, ${ }^{51}$ among others, would not find statistical support. Obviously, the quality assurance and control of supply (among other things) of core components are crucial for the principal firm's competitive advantage. $\mathrm{H} 1$ is rejected.

H2: This hypothesis states that product innovations have a more favorable impact

\section{TABLE 1}

Regression Analysis for Market Performance ${ }^{a}$

\begin{tabular}{|l|c|c|c|}
\hline Variable & $\begin{array}{c}\text { Estimated } \\
\text { coefficient }\end{array}$ & t-Value & $\begin{array}{c}\text { Significance } \\
\text { level }\end{array}$ \\
\hline Intercept & .87 & 2.62 & .01 \\
\hline Internal sourcing & .41 & 2.05 & .04 \\
\hline Internal sourcing**2 & -.13 & -1.15 & .25 \\
\hline Product innovation & .36 & 2.67 & .01 \\
\hline Process innovation & .11 & .95 & .35 \\
\hline Product technology reliance & -.33 & -.76 & .45 \\
\hline Product technology reliance**2 & 1.34 & .89 & .38 \\
\hline Process technology reliance & .93 & 2.44 & .02 \\
\hline Process technology reliance**2 & -2.84 & -2.05 & .04 \\
\hline Vertical control & -.32 & -3.00 & .004 \\
\hline Region & -.83 & -4.10 & .001 \\
\hline
\end{tabular}

$a_{R}^{2}=39.0 \%$, significant at the .0001 level.

Estimated coefficients are $Z$ scores and represent the impact of a change in predictor variables on market performance, expressed in units of standard deviations.

CSOURCE2 is used to represent the extent of internal sourcing.

49. NETER, J. WASSERMAN, William, KUTNER, Michael $H$. Applied linear statistical models, 2nded., Homewood, IL: Richard D. Irwin. 1985.

50. MILES, R. E., SNOW, C. C. Organizations: New concepts for new forrs Calitornia Management Review, v. 28, p. $62-73$, Spring 1986.

51. PRAHALAD, C.K., HAMEL. G., Op. cit. 
52. REICH, R., MANKIN, E. D., Op. cit.

53. HAYES, R. $\mathrm{H}_{\text {., }}$ WHEELWRIGHT, S. C., CLARK, K., Op. cit.

54. ASANUMA, B., 0p. cit; CUSMANO, M., TAKEISHI, A., Op. cit:; RICHARDSON, J., Op. cit. on the firm's market performance than process innovations due to a shortened product life cycle. Findings show that product innovation was found to be highly significant $(p=.01)$, while process innovation was not $(\mathrm{p}=.35)$, although both coefficients were positive as expected. This result clearly shows the importance of product innovation over process innovation, therefore supporting $\mathrm{H} 2$.

H3 and H4: These two hypotheses explore the cost and benefit of the principal firm's reliance on its foreign partner for product development and manufacturing. It was hypothesized that while the principal firm's reliance on its partner for product innovation has a negative impact on its market performance $(\mathrm{H} 3)$, its reliance for process innovation has a positive impact only up to a certain point (H4). For $\mathrm{H} 3$, the linear term for product technology reliance was expected to be negative and statistically significant, and its square term, not to be significant. While the sign for the linear term was negative as expected, it failed to be significant. Therefore, support was not found for $\mathrm{H} 3$.

On the other hand, for $\mathrm{H} 4$, the linear and square terms for process technology reliance were expected to be negative and positive, respectively. Findings unambiguously show that both terms were significant with the expected signs $(p=.02$ and $\mathrm{p}=.04$, respectively). According to the estimation presented in the Note section of Table 1, the impact of process technology reliance on market performance is positive as long as the level of process technology reliance is no more than $38.6 \%$ on a scale of no reliance $(0 \%)$ to complete reliance $(100 \%)$. Since this is a point estimate for an optimum level of process technology reliance, a $95 \%$ confidence interval is computed to be $35.8 \%$ to $41.4 \%(38.6 \pm 2.8)$. Consistent with the view expressed by Reich and Mankin ${ }_{53}^{52}$ and Hays, Wheelwright, and Clark, ${ }^{53}$ among others, this finding suggests that the principal firms heavy reliance on foreign partners for manufacturing process technology has a negative impact on its market performance. Therefore, $\mathrm{H} 4$ is strongly supported.

H5: This hypothesis examines the relationship between the vertical control exercised by the principal firm and its market performance. It was hypothesized that in the absence of ownership related controls, the principal firm can mitigate the risks associated with inter-firm partnerships, and thus, improve market performance, by monitoring and influencing the activities performed by the foreign partner. Accordingly, a positive relationship between vertical control and performance was expected. However, contrary to our expectation, the coefficient has a negative sign and is statistically significant $(\mathrm{p}<.01)$, and thus the results do not support $\mathrm{H} 5$.

\section{CONCLUSIONS AND IMPLICATIONS}

So far, existing research on global sourcing strategy has been based on a closed-systems perspective, and has not addressed how ever-increasing sourcing partnership arrangements affect the performance implications of global sourcing strategy in an open-systems environment. Therefore, the primary objective of this study was to address the limitations of, and extend existing global sourcing research by examining the impact of product and process innovative activities and components procurement on the market performance of firms that have a co-production partnership arrangement. Furthermore, in the absence of ownership related controls in sourcing partnerships, another objective of the study was to examine the performance consequences of the influence exercised by the principal firm on the sourcing partners decisionmaking.

Findings generally support the importance of product and process innovations as well as the principal firm's ability to procure major components in house, as primary determinants of its market performance in sourcing partnerships involving licensing coproduction. These findings are consistent with the closed-systems school of thought rather than with the open-systems school of thought, and thus raise some concern about broad-brush generalization of the alleged benefits of sourcing partnerships as in a Japanese keiretsu.

Earlier studies have unequivocally shown that the firm's ability to procure 
major components in-house has a positive bearing on its market performance irrespective of their actual production location. Aside from a theoretical support from internalization theory and the core competency argument, this observation is consistent with the popular notion of Murphy's Law that a finished product is no better than components that go into it. Therefore, even in a co-production licensing arrangement with a foreign partner, the principal firm's ability to procure and control the supply of major components seems to affect the firm's market performance in the same way as in a solo venture.

This finding could have enormous longterm managerial implications for firms that rely on independent suppliers for major components in the production and marketing of the finished product. In the past twenty years or so, many Western (particularly U.S.) firms have relied heavily on major components manufactured by Japanese and other Asian firms with strong manufacturing capabilities. This sourcing dependency has been criticized as "hollowing-out" of U.S. multinational firms that pursue "an economics of instant gratification, an abdication of responsibilities to future U.S. investors, workers, and consumers". ${ }^{56}$ Long-term dependence on independent suppliers has been argued to cause a principal firm to lose sight of emerging technologies and expertise in the long run. This contention is related to the next issue of product and process innovations, particularly to what extent the principal firm could rely on its co-production partners without relinquishing its ability to maintain its status as a viable player in the industry.

Both product and process innovations have been argued and empirically shown to jointly improve the firm's market performance in a closed-system. In this study, however, product innovations were found to be more important than process innovations as a determinant of the firm's market performance in a sourcing partnership. This finding is consistent with the argument made by proponents of strategic alliances that a principal firm needs a co-production partnership when the "time to market" dimension of competitiveness is crucial, particularly in industries characterized by a rapidly changing technology base.

While our study results agree with the open-systems school of thought, a much more complex picture has also emerged. While process innovations per se may not be a strong determinant of a principal

Findings generally support
the importance of product
and process innovations as
well as the principal firm's
ability to procure major
components in house, as
primary determinants of its
market performance in
sourcing partnerships
involving licensing co-
production.

firm's market performance, its increased reliance on its partner's process capabilities was found to lead to an eventual decline in its market performance. This finding is consistent with the closed-systems school of thought that such dependency is detrimental to the principal firm as process technology is inherently much more difficult to learn than product technology. It seems obvious from this study that U.S. firms tend to find co-production sourcing partnerships crucial in launching new products in foreign markets but their overreliance on partners' manufacturing process capabilities would negate its advantage.

An unexpected departure from our initial theoretical position is the relationship between vertical control exercised by the principal firm and its market performance. This finding has important implications. Recent studies ${ }^{58}$ suggest that firms can achieve the benefits of ownership even in arms-length relationships, as long as vertical control over their partner's decision-making is exercised. Accordingly, such vertical control mitigates the risk of opportunistic
55. WADDELL, William. Overcoming Murphy's law, New York: AMACOM, 1981.

56. Business Week. Special report: The hollow corporation. March 3, p. 56-59. 1986.

57. BROOKS, H., Op. cit.; KOTABE, M. Op. cit., 1992.

58. GROSSMAN, S., HART, O. D. Op. cit.; HEIDI, J. B., Op. cit. 
behavior by the partner firm. In a sourcing relationship, this reasoning implies that a principal firm can ensure a continuous supply of quality components provided by the partner firm through influencing its decision-making. However, the empirical results suggest that although the principal firm has the ability to exercise vertical control, such control adversely affects its performance.

This contrary finding can be partially explained by the research which suggests that centralization of decision-making adversely affects the partner, who is not in a position to respond quickly to changing circumstances. Furthermore, it has been suggested that, in inter-organizational relationships, attempts to influence the decision-making by one firm leads to a frustration-aggression phenomenon from the partner because of perceived lack of autonomy that causes an aggressive retaliatory behavior. ${ }^{59}$ This adversely affects the information exchange and communication between the partner firms, which, in turn, leads to lower performance.

Overall, the results of this study support partially both the closed and open-systems' views of components procurement and technology management in international alliances. The principal firm performance is enhanced if it sources a majority of the important components internally rather than depending on foreign partners. Furthermore, contrary to the suggestion of recent research, ${ }^{60}$ control over decisionmaking of the foreign partners activities adversely affects the principal firm's performance, thus suggesting that the latter cannot mitigate the risks involved in sourcing externally by monitoring the activities performed by the foreign partner. However, as suggested by the proponents of an open-systems view of strategic alliances, the principal firm can enhance its performance through shared product innovations and process technology with its co-production partner. In these cases, the market conditions (such as changing technologies and the need for getting products to the market quickly) necessitate shared innovations for partner firms to compete effectively, and the competitive pressures could outweigh the internalization benefits of doing everything in-house.

\section{LIMITATIONS AND RESEARCH DIRECTIONS}

This study has several limitations. First, the study uses cross-sectional data, thus precluding an examination of dynamic effects of sourcing partnerships. Second, the responding firms in the sample are large multinationals which have the managerial and financial capabilities to source a majority of their components through intra-firm transfers across countries. A future area for research would be to examine the performance implications of sourcing partnerships for smaller firms. Third, the data are collected only from U.S. firms. Since strategic partnerships across countries are necessarily guided by the respective cultural environments of the partner firms, future research is encouraged to replicate this study's findings from the perspective of principal firms from different countries. Fourth, the performance measure used in this study relate to the traditional measures of market share, sales growth rate, and product quality. These may not necessarily reflect the objectives of all firms. For instance, firms may rely on external sourcing from strategic partners to pre-empt competitors in getting a product to the market. Future research should examine the multi-dimensional aspect of performance in sourcing partnerships.

Finally, the study examines performance of only one partner in a sourcing partnership, and therefore does not consider the possibility of crosssourcing in such partnerships. Sourcing partnerships where both partners are equally dependent on each other for major components may have different dynamics from those having unilateral dependence. In addition, this study considers only the structural (i.e., product and process innovations, technology reliance) and control related antecedents of performance in sourcing partnerships. An area of future research would be to study other behavioral dynamics (i.e., trust, commitment, socialization) in crossnational alliances which may afford the firms the benefits of internal sourcing even in inter-firm partnerships. 


\section{Appendix Measurement}

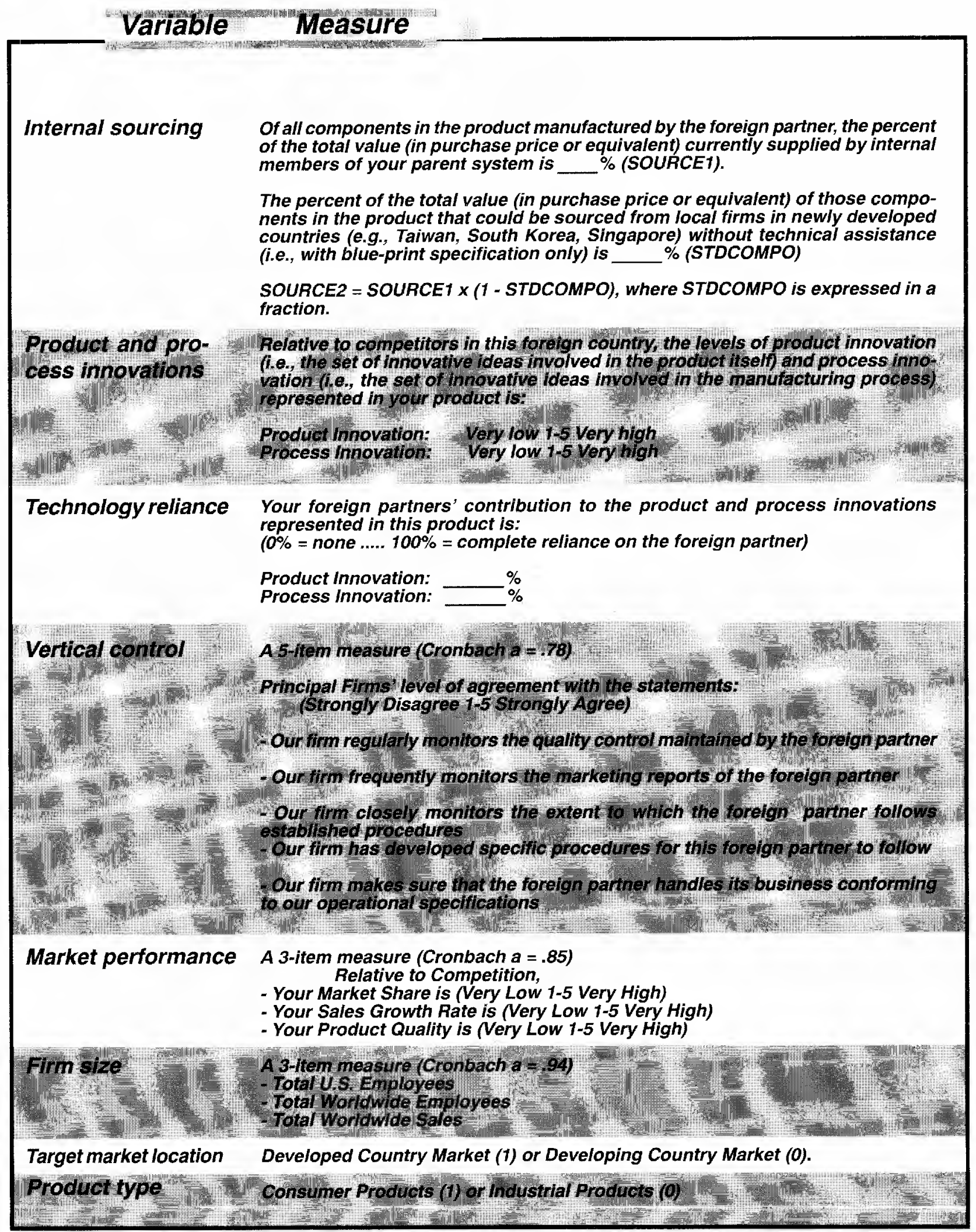

RAE • v. 36 • n. 4 - Out./Nov./Dez. 1996 